\title{
Aquifer characteristics and its modeling around an industrial complex, Tuticorin, Tamil Nadu, India: A case study
}

\author{
N C MONDAL ${ }^{1,2, *}, \mathrm{~V} \mathrm{~S} \mathrm{SINGH}^{1}$ and R RANGARAJAN ${ }^{1}$ \\ ${ }^{1}$ National Geophysical Research Institute (Council of Scientific 6 Industrial Research), \\ Uppal Road, Hyderabad 500 606, India. \\ ${ }^{2}$ Present Address: 321E Scoates Hall, Department of Biological \& Agricultural Engineering, \\ Texas A \& $M$ University, 2117 TAMU, College Station, Texas 77843-2117, USA. \\ *e-mail: ncmngri@yahoo.co.in
}

\begin{abstract}
Anthropogenic pollution of shallow groundwater resources due to industrial activities is becoming a cause of concern in the east coastal belt of the state of Tamil Nadu, India. Integrated hydrogeological, geophysical and tracer studies were carried out in the coastal region encompassing an industrial complex. The objective has been to gain knowledge of aquifer characteristics, ascertaining groundwater movement and its flow direction, which would in turn reveal the possibility of contamination of groundwater regime and its better management. The results of multi-parameters and model study indicate that the velocity of groundwater flow ranges from $0.013 \mathrm{~m} / \mathrm{d}$ to $0.22 \mathrm{~m} / \mathrm{d}$ in and around the industrial complex in upstream western part of the catchment and $0.026 \mathrm{~m} / \mathrm{d}$ to $0.054 \mathrm{~m} / \mathrm{d}$ in the downstream eastern part, near the coast. These parameters are vital for the development of groundwater management scheme.
\end{abstract}

\section{Introduction}

Shallow and moderate depth groundwater resources up to $50 \mathrm{~m}$ depth in coastal belt of Tamil Nadu, India are being utilized for drinking and irrigation needs. There are exploitation pressure on this limited groundwater resources and growing concern of deterioration of groundwater quality due to anthropogenic activities such as unplanned disposal of industrial effluents, sewerage, etc.

Several industrial activities are in operation near the coast at a distance of about $8 \mathrm{~km}$ west of Tuticorin town, in the east coastal belt of the state of Tamil Nadu, India. The deterioration of groundwater quality in future is the concern of people around these industries and further saline water incursion may add to the problem. Detailed investigations were carried out around these complexes. The specific objectives of the studies are to evaluate hydrogeological parameters, ascertain groundwater movement, its flow direction and to use the data for preparation of an aquifer model for the area encompassing the complex to visualize possible threat due to pollution migration.

\section{Study area}

The study area (latitude: $8.77^{\circ}$ and $8.85^{\circ} \mathrm{N}$ and longitude: $78.04^{\circ}$ and $78.17^{\circ} \mathrm{E}$ ) falls in east coastal belt, west of Tuticorin town in the state of Tamil Nadu, India. The area forms a watershed (drainage area encompassing an industrial complex), and occupy about $112 \mathrm{~km}^{2}$ (figure 1). The watershed is drained by stream network oriented in NW-SE direction, ends up in small tanks and is of ephemeral in nature. The topographic elevation

Keywords. Groundwater pollution; resistivity; tracer; modeling; groundwater velocity; coastal belt. 


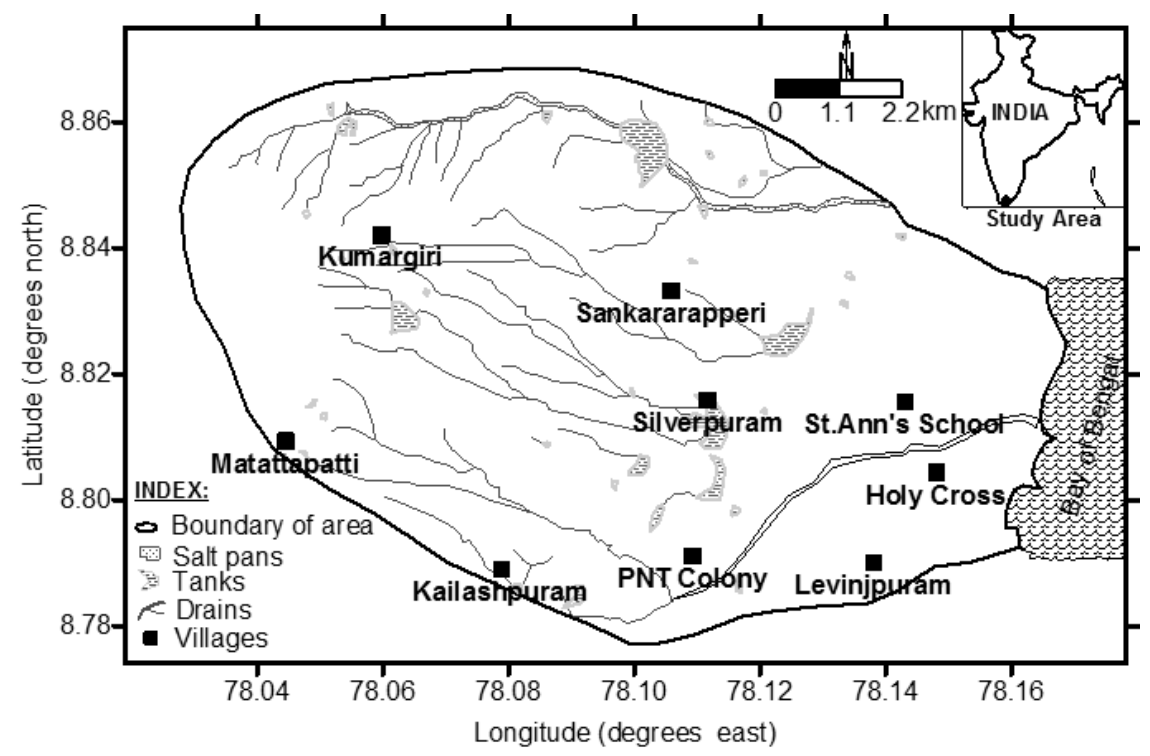

Figure 1. Study area and drainage pattens of a watershed, Tuticorin, Tamil Nadu, India.

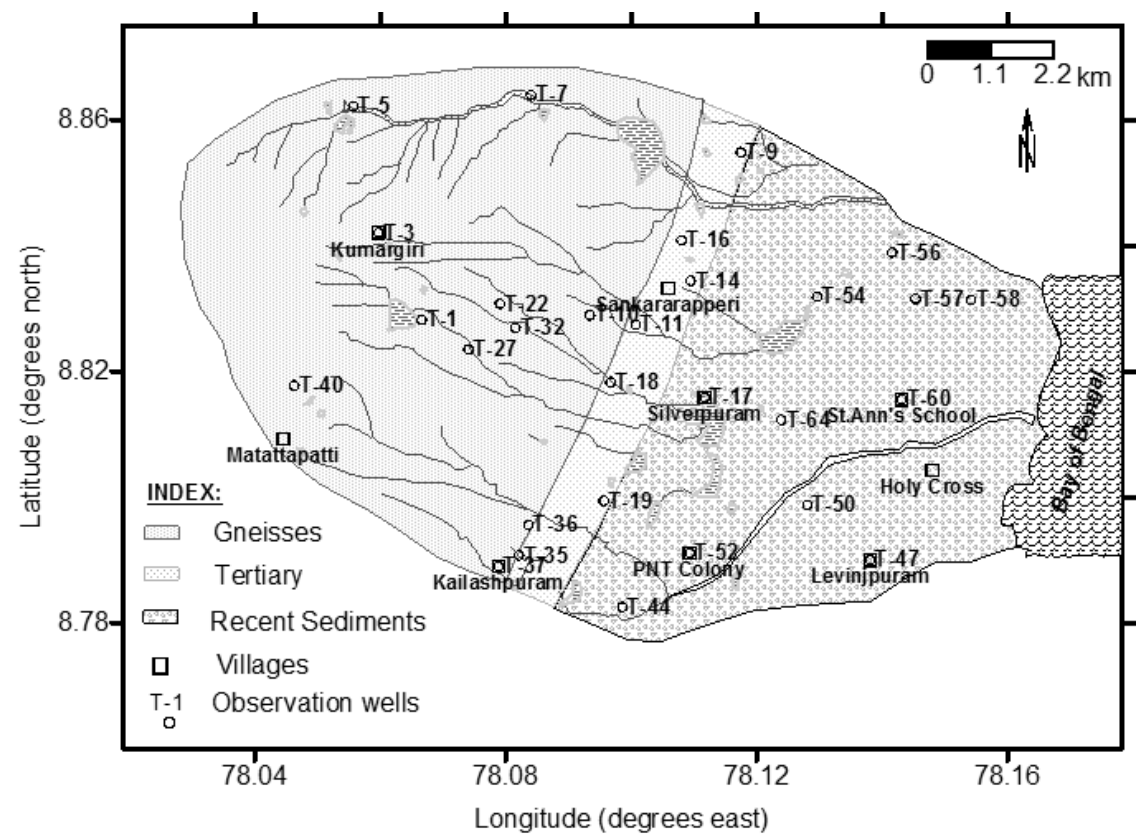

Figure 2. Geology map (gneisses in western site, Tertiary in middle and Recent sediment in the eastern site) and also showing the location of observation wells.

of the watershed varies from $27.00 \mathrm{~m}$ (amsl) in the catchment area to few meters (amsl) near the coast and slopes from west to east. The slope is gentle in western and central parts and more or less plain in eastern part of the watershed. The area experiences semi-arid tropical climatic condition and the long term average annual rainfall is $568 \mathrm{~mm}$. The watershed area is underlain by Archaean complex, tertiary and recent group of formations (figure 2). Archaean group of rocks occupy western part of the watershed. The rocks include ridges of quartzites, bands of charnockites and peninsular gneisses which are weathered, jointed and fractured at places. The tertiary formation overlies the Archaean complex with marked unconformity, consists of calcareous sandstone and shaley limestone. These are medium-to-fine grained, compact and fossiliferous in nature. The thickness of the formation varies from few to few tens of meters. Recent to sub-recent sand occupies most of the coastal areas. It consists of coarse and calcareous grits, sandstone, shaley limestone. Accumulation 
of wind blown sands and shale's constitute beach sand and coastal dunes. The watershed area is covered with black soils originated from charnockites and gneisses in the upstream catchment area in the west, red soils (sandy loam to sandy) in the central part and alluvial sandy soils in the downstream eastern part. The land is utilized for cultivation of cotton, maize and some medicinal plants. Some of the land is fallow and some is barren with vegetation such as thorny shrubs with thin cover of dry grass and palms. The watershed area has large number of open wells and bore wells tapping shallow phreatic and fractured aquifer system. The wells are being used for domestic and irrigation purposes. The electrical conductivity of groundwater in the watershed area varies from 150 to $17,597 \mu \mathrm{S} / \mathrm{cm}$ at $25^{\circ} \mathrm{C}$.

\section{Materials and methods}

Hydrogeological, geophysical investigations (resistivity survey) and tracer studies were carried out for deciphering subsurface litho zones, understanding prevailing hydrogeological conditions, evaluation of aquifer parameters such as recharge, specific yield/storage coefficient, hydraulic conductivity, etc. Groundwater levels in and around an industrial complex, Tuticorin were monitored using water level indicator (IGIS, Hyderabad) at 32 observation wells during pre- and post-monsoons. A total of 33 Vertical Electrical Soundings (VES) were conducted using Schlumberger electrode configuration for a spreading of 50-100 m. Initially VES data have been interpreted through curve matching technique (Orellana and Mooney 1966) and then interpreted by computer program, which involves the inverse modeling method (Vender Velpen 1988). Ten sites were selected for the estimation of natural recharge by the injected tritium tracer technique (Rangarajan and Athavale 2000). To estimate the aquifer properties, pumping test was carried out at 10 locations on the area and the data were analyzed by numerical method (Singh 2000). The data generated was utilized for the development of aquifer flow model (Anderson and Woessner 1992). The various steps involved in groundwater flow modeling are shown in figure 3. The calculated groundwater velocity was compared with the velocity obtained from the borehole tracer test (Drost et al 1974) at a selected site of inside the industrial complex.

\subsection{Hydrogeological investigations}

Groundwater occurs in the weathered and fractured zones of gneisses and sandy aquifers in sedimentary and alluvial formations. In order to assess

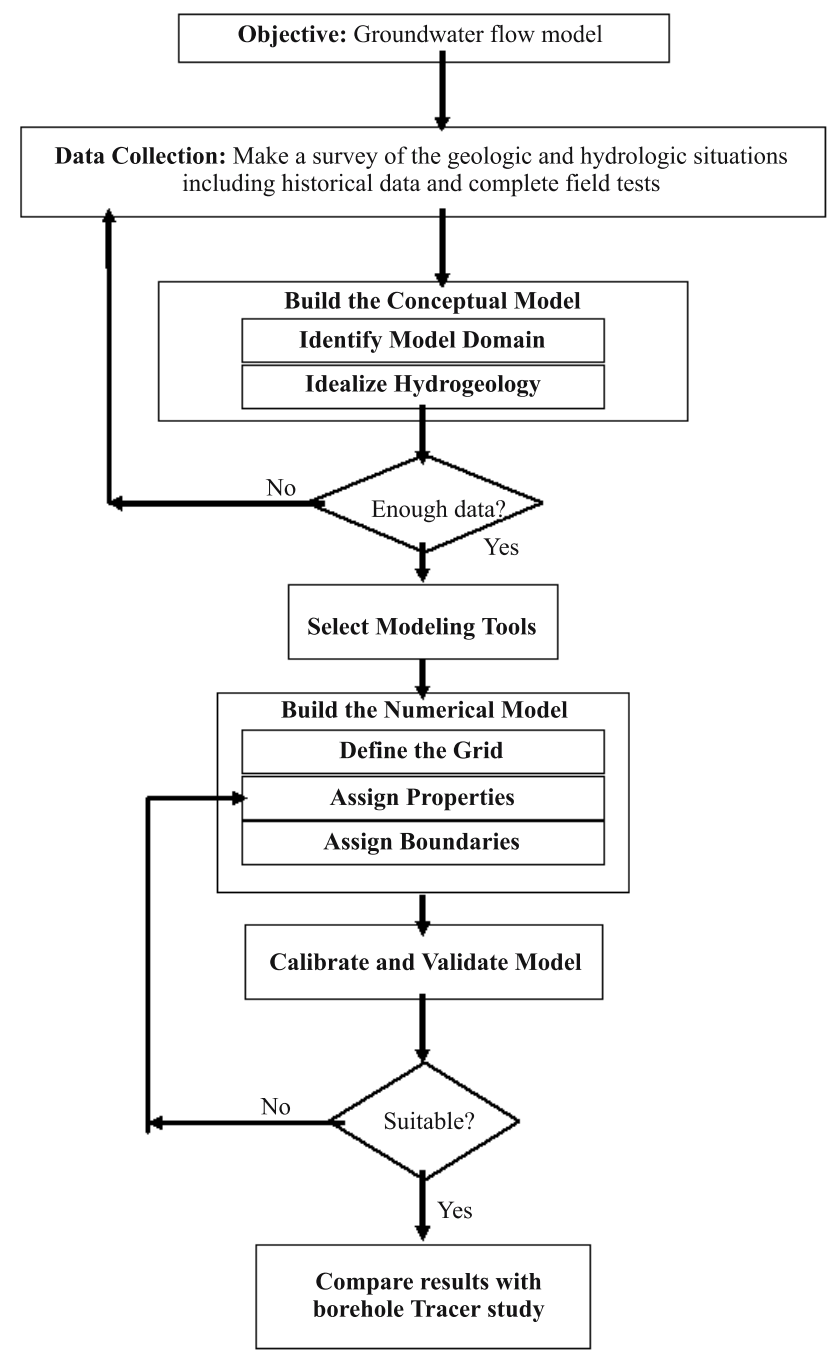

Figure 3. Flow chart for groundwater flow model.

the groundwater regime, well inventory have been carried out in the area (Singh et al 2006). Various parameters such as location, diameter, depth of well, depth of water level, well use, quality have been recorded/measured from selected open and bore wells (as shown in figure 2). The static water level in wells during the pre-monsoon period varies from $1.81 \mathrm{~m} \mathrm{(bgl)}$ to $16.4 \mathrm{~m} \mathrm{(bgl)}$ and in post-monsoon period it is from $0.86 \mathrm{~m}$ (bgl) to $13.49 \mathrm{~m}$ (bgl) (table 1). The shallow groundwater has been recorded in bore wells located inside the industrial complex and in open wells near the coast. Deep water table conditions $(>14 \mathrm{~m})$ observed in wells at localized pockets and are mainly due to the exploitation of groundwater for domestic/irrigation purposes. The well inventory data indicates that seasonal rainfall causes $0.49 \mathrm{~m}$ to $5.95 \mathrm{~m}$ water level rise with an average value of $1.50 \mathrm{~m}$ in the area. Electrical conductivity (EC) varies from 200 to $17,597 \mu \mathrm{S} / \mathrm{cm}$ in premonsoon but in post-monsoon it is from 150 to $17,200 \mu \mathrm{S} / \mathrm{cm}$. 
Table 1. Water quality and static water levels in observation wells in the watershed area.

\begin{tabular}{|c|c|c|c|c|c|c|c|}
\hline \multirow[b]{2}{*}{ Well code } & \multirow[b]{2}{*}{ Village name } & \multirow{2}{*}{$\begin{array}{l}\text { Type } \\
\text { of well }\end{array}$} & \multirow{2}{*}{$\begin{array}{l}\text { Depth } \\
\text { of well } \\
(\mathrm{m})\end{array}$} & \multicolumn{2}{|c|}{ July 2006} & \multicolumn{2}{|c|}{ January 2007} \\
\hline & & & & WL & $\mathrm{EC}$ & WL & $\mathrm{EC}$ \\
\hline $\mathrm{T}-1$ & Terku Virapadiyapuram & TW & 70.00 & 14.24 & 4850 & 11.70 & 3960 \\
\hline $\mathrm{T}-3$ & Kumargiri & TW & 70.00 & 16.40 & 3370 & 13.49 & 1545 \\
\hline $\mathrm{T}-5$ & Swaminatham (S) & DW & 12.00 & 5.81 & 6000 & 4.01 & 5900 \\
\hline $\mathrm{T}-7$ & Nayinapuram & TW & 54.86 & 11.31 & 500 & 7.60 & 510 \\
\hline T-9 & Pudur Pandiyapuram & DW & 8.40 & 6.33 & 400 & 4.76 & 300 \\
\hline $\mathrm{T}-10$ & Pandarampatti & BW & 70.00 & 8.60 & 7900 & 7.70 & 8000 \\
\hline $\mathrm{T}-11$ & Pandarampatti (W) & TW & 33.52 & 8.99 & 2230 & 7.05 & 1965 \\
\hline $\mathrm{T}-14$ & Sankararapperi (E) & DW & 10.00 & 7.35 & 6300 & 6.40 & 6500 \\
\hline $\mathrm{T}-16$ & Ramanathampuram & DW & 11.50 & 9.10 & 1846 & 7.65 & 1739 \\
\hline $\mathrm{T}-17$ & Silverpuram & DW & 9.00 & 7.87 & 10380 & 7.20 & 6620 \\
\hline $\mathrm{T}-18$ & Milavittam & DW & 12.40 & 9.72 & 4600 & 8.23 & 6880 \\
\hline $\mathrm{T}-19$ & Madathur (N) & DW & 9.00 & 6.58 & 2200 & 5.81 & 2100 \\
\hline $\mathrm{T}-22$ & SIIL-II (N, PZ-11) & BW & 18.28 & 5.88 & 12290 & 5.30 & 11040 \\
\hline $\mathrm{T}-27$ & SIIL-VII (W, PZ-2) & BW & 18.28 & 2.55 & 5300 & 1.30 & 4560 \\
\hline $\mathrm{T}-31$ & SIIL-XI (N) & BW & 18.28 & 5.02 & 7300 & 3.86 & 7350 \\
\hline $\mathrm{T}-32$ & SIIL-XII (W, PZ-6) & BW & 18.28 & 4.56 & 9300 & 3.20 & 9350 \\
\hline $\mathrm{T}-35$ & Ayynaduppu & DW & 10.66 & 6.48 & 5230 & 4.72 & 5180 \\
\hline $\mathrm{T}-36$ & A. Shunmughapura & DW & 8.60 & 6.98 & 3100 & 5.70 & 3000 \\
\hline $\mathrm{T}-37$ & Kailashpuram & DW & 6.30 & 5.38 & 200 & 4.78 & 150 \\
\hline $\mathrm{T}-40$ & Vadakka Silukkanpatti (E) & TW & 60.00 & 14.45 & 3300 & 8.50 & 3200 \\
\hline $\mathrm{T}-41$ & Madattupatti & DW & 12.32 & 11.63 & 3300 & 8.52 & 3000 \\
\hline $\mathrm{T}-44$ & Periyanayakapuram & DW & 4.58 & 3.81 & 4800 & 2.15 & 5000 \\
\hline $\mathrm{T}-47$ & Levinjpuram & DW & 6.25 & 5.36 & 4500 & 4.38 & 4850 \\
\hline $\mathrm{T}-50$ & Seetapuram Nagar & DW & 2.96 & 1.81 & 1700 & 0.86 & 2090 \\
\hline $\mathrm{T}-52$ & PNT Colony (S) & DW & 3.20 & 2.81 & 900 & 1.50 & 690 \\
\hline $\mathrm{T}-54$ & Mappali Urani & DW & 5.50 & 5.18 & 12600 & 4.37 & 12800 \\
\hline $\mathrm{T}-56$ & Davishpuram & DW & 6.88 & 6.55 & 9100 & 5.81 & 9600 \\
\hline $\mathrm{T}-57$ & Arokayipuram & DW & 5.96 & 5.26 & 7200 & 4.63 & 9100 \\
\hline $\mathrm{T}-58$ & Rajapallam & DW & 5.83 & 4.69 & 2100 & 3.72 & 1970 \\
\hline T-60 & SBI Colony (St. Ann's School) & DW & 4.09 & 3.44 & 2800 & 2.58 & 3050 \\
\hline $\mathrm{T}-62$ & Holy Cross Girls School & DW & 3.77 & 3.46 & 900 & 2.54 & 1100 \\
\hline $\mathrm{T}-64$ & Chinakannupur (Milivattam road) & DW & 6.75 & 3.34 & 17597 & 2.85 & 17200 \\
\hline
\end{tabular}

WL: Water level; TW: Tube well; DW: Dug well; BW: Bore well; EC: Electrical conductivity at $25^{\circ} \mathrm{C}$.

\subsection{Geophysical investigations}

The resistivity sounding technique (Compagnie Generale de Geophysique 1963; Orellana and Mooney 1966; Bhattacharya and Patra 1968; Rijkswaterstaat 1969) was employed to delineate geoelectrical subsurface structures in the watershed area. Resistivity sounding was carried out at 33 locations (as shown in figure 4) in the watershed with current electrode separation varies from 50 to $100 \mathrm{~m}$. The curves obtained are classified as $\mathrm{HKH}, \mathrm{KA}, \mathrm{AA}, \mathrm{AH}, \mathrm{HA}, \mathrm{KH}, \mathrm{H}, \mathrm{A}, \mathrm{HKA}$, KHA-types, which describe the variation in the resistivity of progressive layers below ground surface (Singh et al 2006). There are four basic types of sounding curves depending upon the resistivity distribution with depth. If $\rho_{1}, \rho_{2}$ and $\rho_{3}$ are the resistivities of the three subsurface layers beginning with $\rho_{1}$ at the top, then $\rho_{1}>\rho_{2}<\rho_{3}$ is defined as H-type, $\rho_{1}<\rho_{2}<\rho_{2}$ as A-type, $\rho_{1}<\rho_{2}>\rho_{3}$ as K-type and $\rho_{1}>\rho_{2}>\rho_{3}$ as Q-type. In multilayer earth, a number of these combinations can exist. The observed field curves are matched with theoretical master curves to get initial parameters and finally these are used as initial inputs in the interpretation of resistivity data through software namely RESIST (Vander Velpen 1988). A typical cross-section of the subsurface from west to east direction is shown in figure 5. It shows that the elevation of aquifer varies from $13.0 \mathrm{~m}$ (amsl) to few meters below mean sea level (bmsl). In order to get representative subsurface parameters, the local 


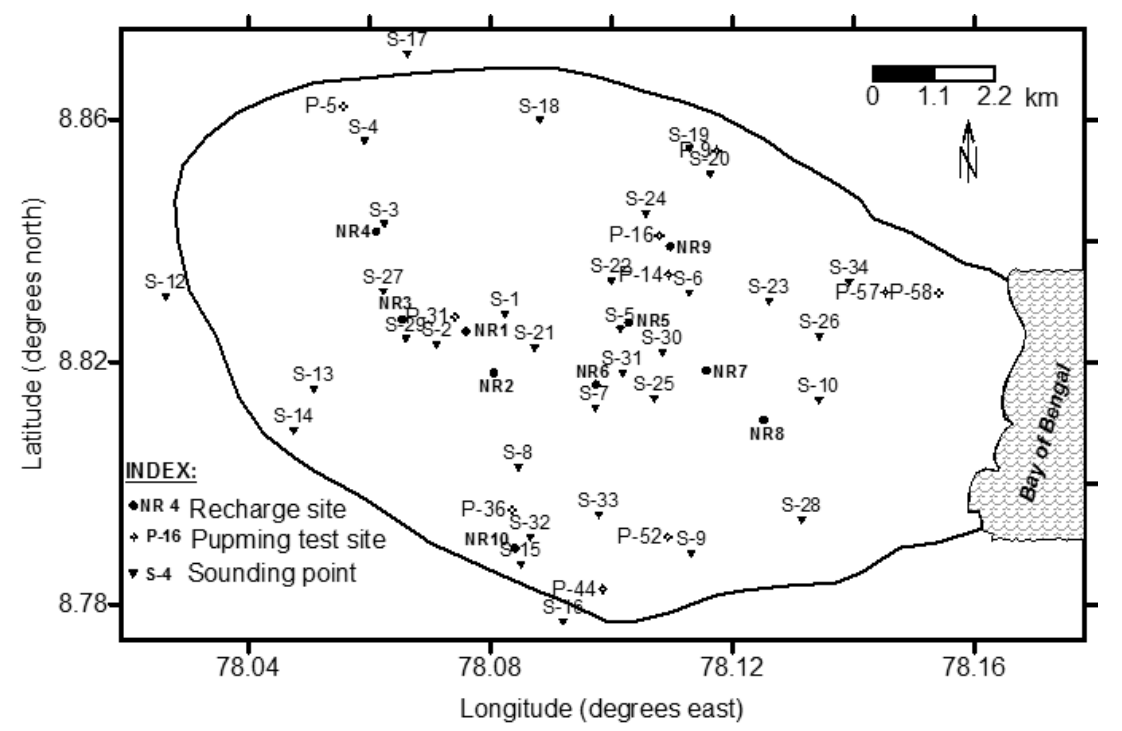

Figure 4. Location of sounding points, pumping test and recharge sites.



Figure 5. Cross-section view of geoelectrical layers (W-E direction).

hydrogeology have also been taken into account. The data generated, resistivity sounding results reported by Balasubramanian (1993) and available litholog data (Sankul Techno 2002) were considered to arrive at descriptions of subsurface strata for the gneissic terrain. The elevation of the first 


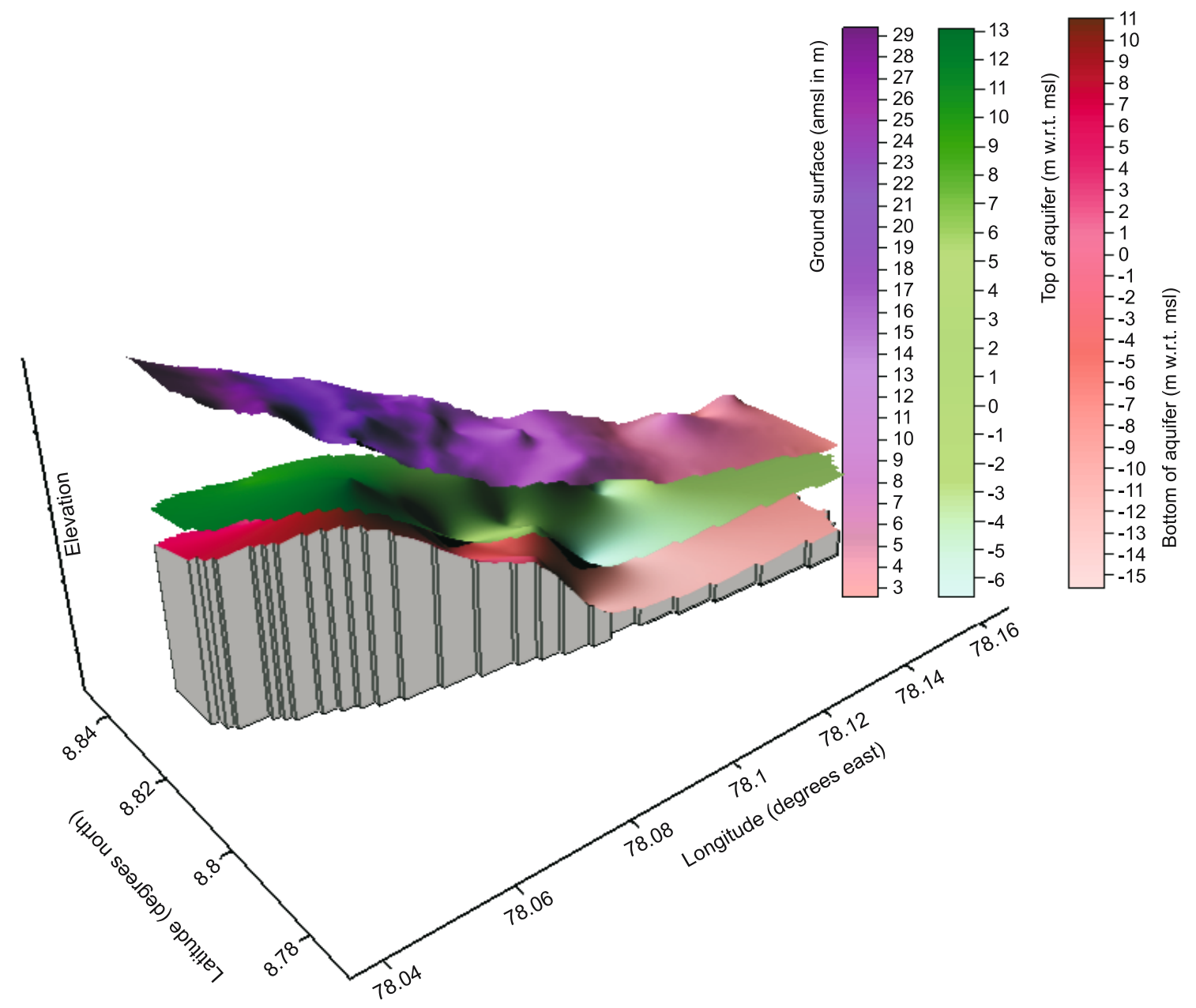

Figure 6. Shallow aquifer system in the modeled area.

shallow aquifer varies from -6.00 to $13.00 \mathrm{~m}$ (amsl) while the bottom varies from -15.00 to $11.00 \mathrm{~m}$ (amsl). The 3-D map of shallow aquifer distribution of the study area was prepared with the help of computer software SURFER v.8.0 using kriging method as shown in figure 6 .

\subsection{Tracer studies}

\subsubsection{Tritium injection method}

Injected tritium tracer technique (Munnich 1968; Athavale et al 1980; Rangarajan and Athavale 2000) based on the model on layered movement of water infiltration in the vadoze zone was used for natural recharge (recharge caused by rainfall) measurements in the watershed area. In the study area, measurements were made at 10 sites for estimating natural recharge caused by 2006 seasonal rainfall (figure 4). The sites selected are fallow non-agricultural land or rain-fed agricultural fields and care has been taken to select the site nearby one of the observation wells being monitored. The tracer was injected at the depth of $60 \mathrm{~cm}$ below ground level (bgl) using drive rod having diameter of $10 \mathrm{~mm}$ in the month of July 2006. Vertical soil samples were collected in $20 \mathrm{~cm}$ section using recovery pipes having varying lengths and diameter of $45 \mathrm{~mm}$ up to maximum depth of $3.0 \mathrm{~m}$ in the month of January 2007 after the completion of monsoon. The depth samples were analyzed in the laboratory for moisture content through gravimetric method and tracer concentration using liquid scintillation counter. The recharge value for each site is calculated first by determining the center of gravity of the tritium versus depth profile and the moisture content of the displaced zone. The displacement of tracer from the depth of injection is the distance between injection depth and center of gravity or peak of the tritium concentration in the profile. The recharge is calculated by:

$$
R_{e}=m \times d
$$

where $R_{e}=$ recharge in $\mathrm{mm}, m=$ moisture content of the displaced zone in $1 \mathrm{~mm}^{2}, d=$ displacement of tracer from the depth of injection. 
$R_{e}$ is the height of an imaginary water column over $1 \mathrm{~mm}^{2}$ in the soil profile between the depth of injection and peak in tritium activity. As per the piston flow model, this amount is finally added to the groundwater as recharge. Assuming this ' $R_{e}$ ' is due to rainfall ' $R$ ' during time ' $t$ ' (period between dates of injection and soil core collection), the percentage of rainfall $R$ contributing to the recharge is given as,

$$
R_{e}(\%)=100 \times d \times m / R .
$$

At each site natural recharge was computed using moisture and tritium tracer distribution data (presented in table 2). Tritium profiles observed at various sites are shown in figure 7 . The mean natural recharge computed from 9 sites is $63.6 \mathrm{~mm}$ for the average rainfall of $581 \mathrm{~mm}$ (Rangarajan et al 2007). This is equivalent to $10.9 \%$ of the rainfall.

\subsubsection{Borehole tracer (Bromide method)}

Borehole tracer experiment was carried out at a selected site inside the industrial complex for determining natural groundwater velocity. Artificial chemical tracer bromide in the form of potassium bromide was used in the experimental investigation through single well dilution technique based on the principle of Darcy law (Rangarajan et al 2007). In the single well method, if the groundwater column of a filter tube/borehole is labeled with a tracer solution, the decrease in the concentration of this solution is a function of groundwater flow in the well (Drost et al 1974; Kulkarni and Sharma 2004). Groundwater filtration velocity $\left(v^{*}\right)$ is given as,

$$
\begin{aligned}
Q & =\frac{V}{t} \ln \left(\frac{C_{0}}{C}\right), \\
v^{*} & =-\frac{V}{A t} \ln \left(\frac{C}{C_{0}}\right) .
\end{aligned}
$$

It can also be expressed as (Kulkarni and Sharma 2004):

$$
\begin{aligned}
& v^{*}=\left(\frac{\Pi r}{2 \dot{\alpha} t}\right) \ln \left(\frac{C_{0}}{C}\right), \\
& v^{*}=p n \times v,
\end{aligned}
$$

where, $Q=$ groundwater discharge from the filter tube, $V=$ volume of labeled water column, $C_{0}=$ concentration of the labeled water column at time $t=0, C=$ concentration of the labeled

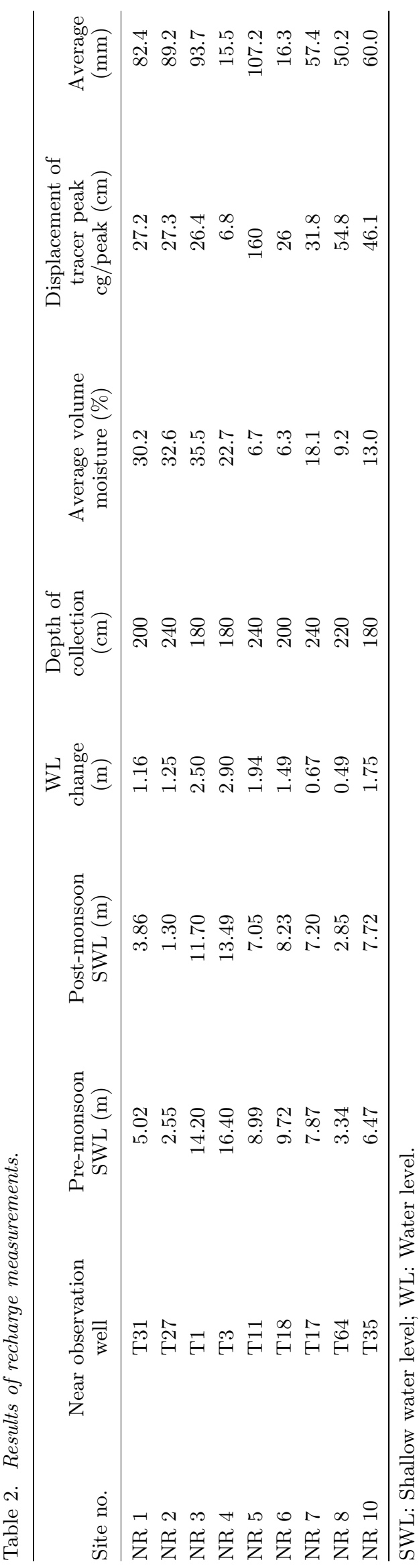



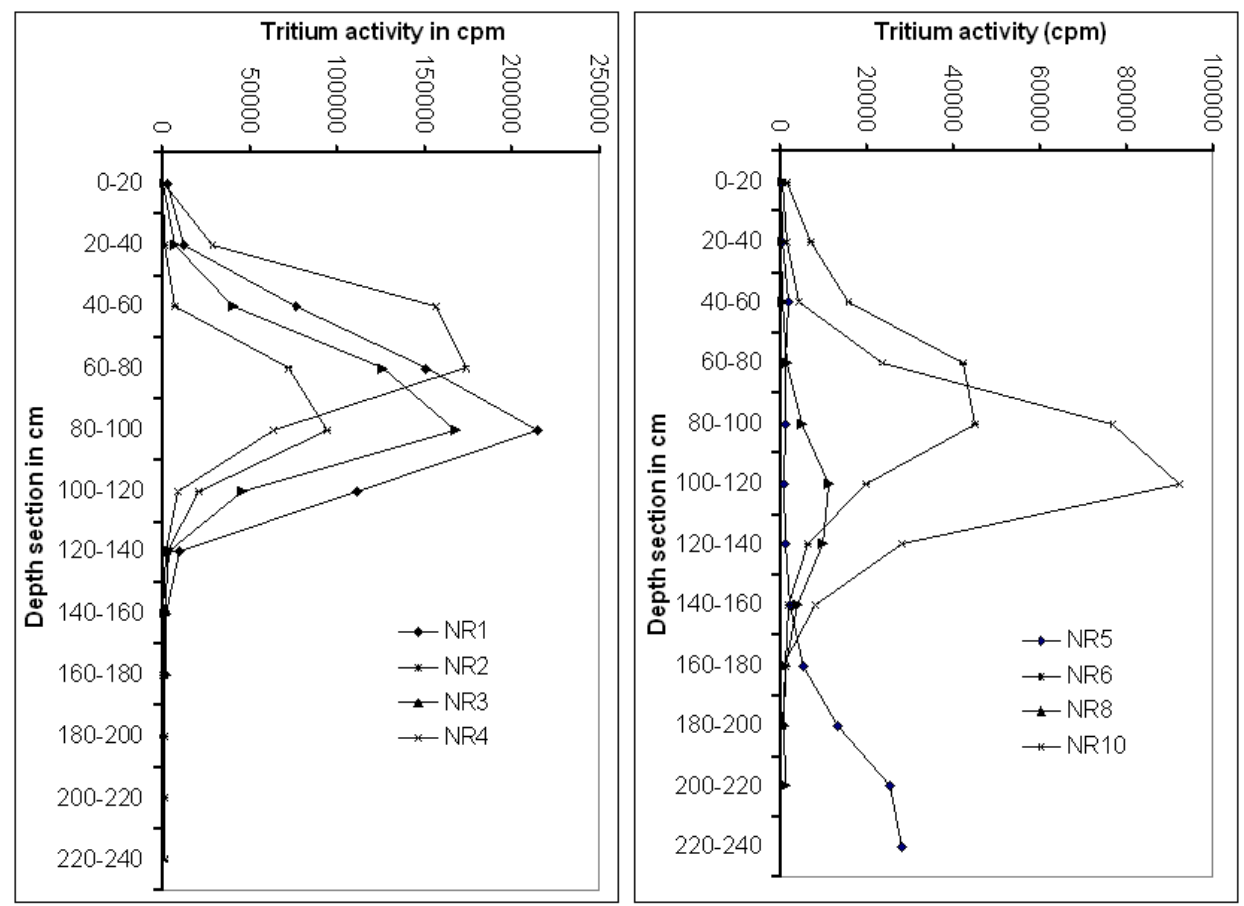

Figure 7. Tritium profiles for natural recharge sites.

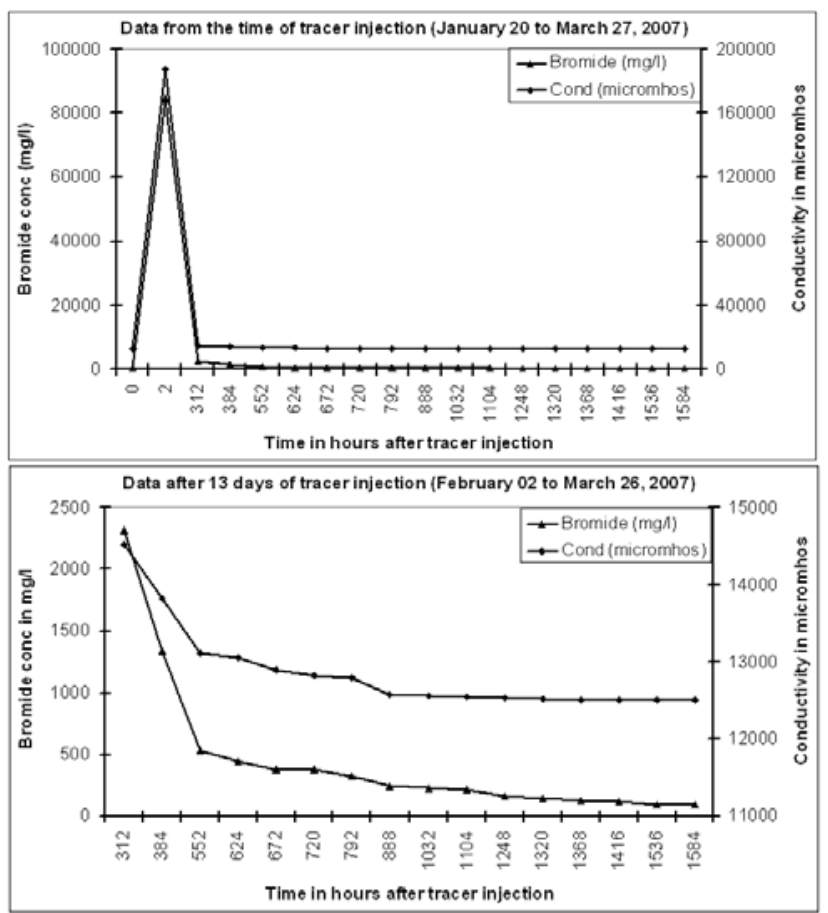

Figure 8. Bromide and conductivity data of tracer injected site (a) from the time of tracer injection (January 20 to March 27, 2007) and (b) after 13 days of tracer injection (February 02 to March 26, 2007).

water column at time $t, A=$ flow cross section area of the tube, $r=$ internal radius of filter tube, $\dot{\alpha}=$ a constant (function of hydraulic conductivity of the well screen, gravel material and the aquifer) in the case of well construction with gravel pack, $v^{*}=$ filtration velocity, $p n=$ effective porosity of the aquifer, and $v=$ distance velocity of groundwater.

The conductivity and bromide concentration of water samples collected from the injection well for the period plotted is shown in figure 8. The figure shows conductivity and bromide concentration decreases exponentially. The decrease in bromide concentration is similar to the reduction in conducti vity values. A section of the data after several days of tracer injection was taken for determining the velocity of groundwater flow. The average filtration velocity calculated was $0.002 \mathrm{~m} / \mathrm{d}$. The effective porosity of weathered gneiss is considered as $6 \%$ by Kumar et al (2000) for the hydrological studies carried out by them. The effective porosity/specific yield of the weathered gneiss formation for the watershed area calculated using water level change and recharge data is $5.8 \%$. Using this value the actual velocity of groundwater flow inside the industrial complex is calculated as $0.034 \mathrm{~m} / \mathrm{d}$. The velocity of the groundwater flow is calculated neglecting the density currents arising from concentration and temperature differences, vertical groundwater movements in the borehole, molecular diffusion, effect due to artificial mixing of tracer in the borehole, etc.

\subsection{Aquifer characterization}

In order to assess groundwater potential in any area, and/or to evaluate the impact of pumpage 


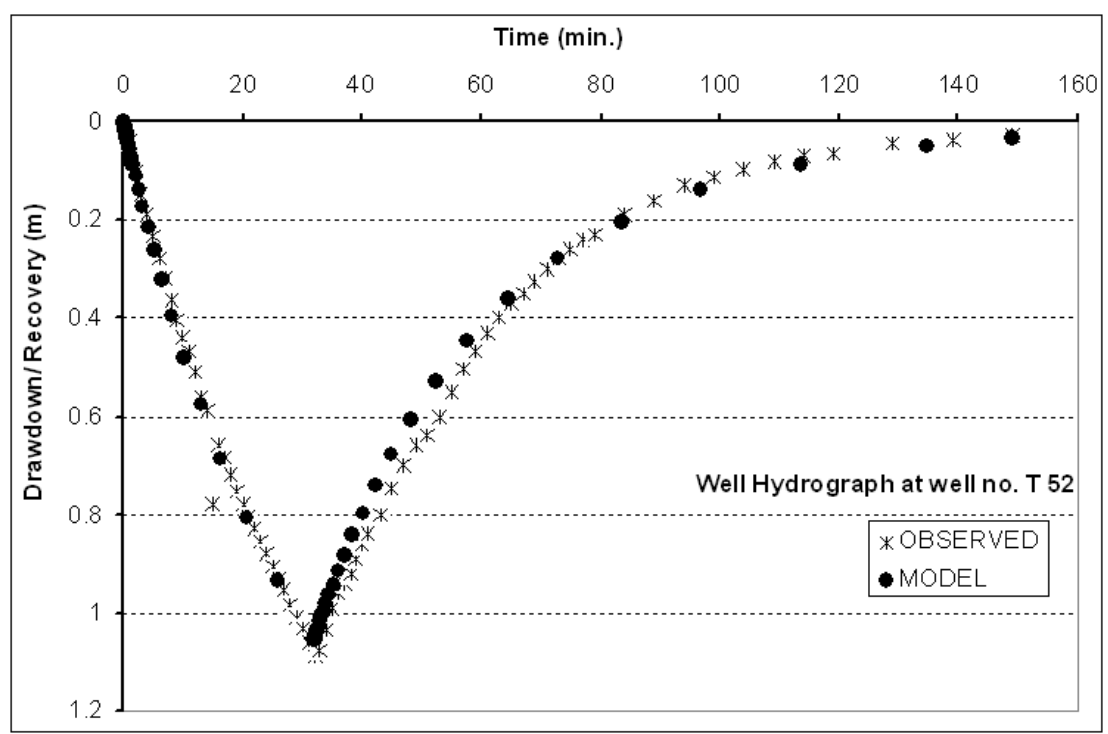

Figure 9. Time versus drawdown/recovery at well P-52.

on the groundwater regime, it is essential to know the aquifer parameters. These are mainly transmissivity $(T)$ and storativity $(S)$. These parameters are also vital for the management of groundwater resources through the use of groundwater flow model. There are several analytical methods developed to estimate aquifer parameters, however, the numerical approach has the advantage in incorporating the actual field conditions with ease and hence the parameters estimated becomes realistic. The method is described in detail by Rushton and Redshaw (1979) and Singh (2000).

During the field investigations, the existing wells have been selected to carry out pumping test. Ten such wells spread in the study area have been selected for carrying out pumping tests. The location of these wells is shown in figure 4. Most of these wells have been kept without pumping prior to begin the test and water levels have been continuously being monitored. All these wells were of large diameter (six of these are rectangular) except one, i.e., P-31 which has diameter of $0.102 \mathrm{~m}$. The existing pumps fitted on the wells have been used to carry out pumping test. The time-drawdown/recovery data for all the tests have been plotted on linear scale and a typical time/drawdown plot is shown in figure 9. The interpretation of test data has been carried out using forward modeling technique as suggested by Singh (2000). The nearby features such as water body or lateral inhomogeneities have been incorporated into individual interpretation. Initial guess parameters have been considered to generate timedrawdown curve for individual test and compared with the observed time-drawdown/recovery data. The aquifer parameters were varied till a close match is obtained. The best fit match is considered as representative aquifer parameters. One of the typical best fit matches is shown in figure 9 . The transmissivity has been found to vary from 0.8 to $80.0 \mathrm{~m}^{2} / \mathrm{d}$ (presented in table 3 ).

\section{Aquifer modeling}

\subsection{Conceptualization}

In order to understand groundwater regime, all the data such as hydrogeological, geophysical, hydraulic tests and tracer results (Singh et al 2006, 2007; Singh and Mondal 2008; Rangarajan et al 2007) were analyzed to conceptualize the aquifer system. Further, the subsurface geological information described by Balasubramanian et al (1993) has also been taken into account. The area in the upper part of the watershed has been selected to model and prepare groundwater flow regime.

The geometry and boundary conditions in the study area are generally complex. The analytical methods are rarely applicable to find a closed form solution of the partial differential equations of 2-D groundwater flow equation (Rushton and Redshaw 1979) as follows:

$\frac{\partial}{\partial x}\left(\frac{K_{x x} \partial h}{\partial x}\right)+\frac{\partial}{\partial y}\left(\frac{K_{y y} \partial h}{\partial y}\right)=S_{s}\left(\frac{\partial h}{\partial t}\right) \pm W$

where $K_{x x}$ and $K_{y y}$ are the hydraulic conductivity along $x$ - and $y$-directions respectively, $h$ is the hydraulic head, $S_{s}$ is the specific storativity, $W$ is the groundwater volume flux per unit area 
positive for outflow and negative for inflow, and $x$ and $y$ are the Cartesian co-ordinates. This equation is, therefore, replaced by approximate ones which are traceable by numerical methods. The most commonly used techniques are the finite element and finite difference methods. In this study, only the finite difference approximation technique is used as it is easy to handle for numerical computations. The starting point for the application of this method is discretization of small rectangular sub-regions in a grid form. The partial differential equations hereby, replaced by a finite different equation at each node. Several techniques such as iterative alternating direct procedure and successive over-relaxation methods, etc., are available for solving the set of resultant simultaneous algebraic equations.

The drainage pattern has been made as the basis for demarcation of limit of the area. In this area, drainage is mostly ESE joining two major tanks. Based on the geological information and data obtained from geophysical investigation, single layer model was conceptualized for the simulation of shallow aquifer. There may be multi-aquifer system available, but below the first (shallow) aquifer, clay formation is encountered in the study area. The boundary conditions as observed in the field have been assigned. The sea boundary in the eastern side has been assigned as a constant boundary with head at zero. The model area was divided in to $100 \times 100$ cells, each of the size of $132 \mathrm{~m} \times 85 \mathrm{~m}$. The elevation of the first shallow aquifer varies from -6.00 to $13.00 \mathrm{~m}$ (amsl) while the bottom varies from -15.00 to $11.00 \mathrm{~m}$ (amsl). Both top and bottom layers elevation of single layer aquifer was prepared with respect to above mean sea level (amsl) in grid form with the help of SURFER v.8.0 using kriging method and converted into ASC-format, which is imported into the model under MODFLOW environment. A typical view of 31 column in NS direction is shown in figure 10(a). The elevation varies from about $10 \mathrm{~m}$ (amsl) to $4 \mathrm{~m}$ (amsl). The column is across well no. 32. Similarly, the vertical section across 34 row in WE direction is shown in figure $10(\mathrm{~b})$.

The elevations of the measurement points (MP) of observation wells were connected from bench mark with the help of Tri-Angular Survey. Geoelectrical layers were obtained from the resistivity survey. Based on the geological information and data obtained from geophysical investigation, aquifer dimensions were assigned from the mean sea level $(\mathrm{msl})$. The elevation of aquifer varies from $10 \mathrm{~m}$ (amsl) to few meters below mean sea level (msl). The aquifer section passes across well no. 32. Based on the pumping test result as briefly described above (Singh et al 2007), the conductivity of aquifer is assigned. Consideration is also given to

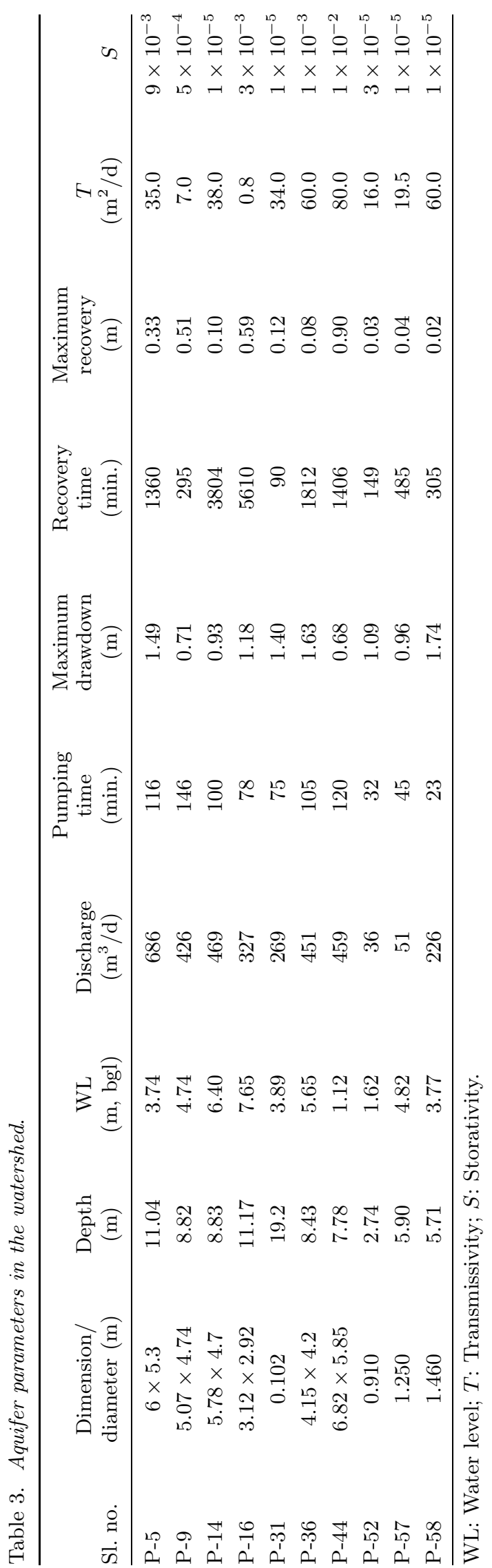



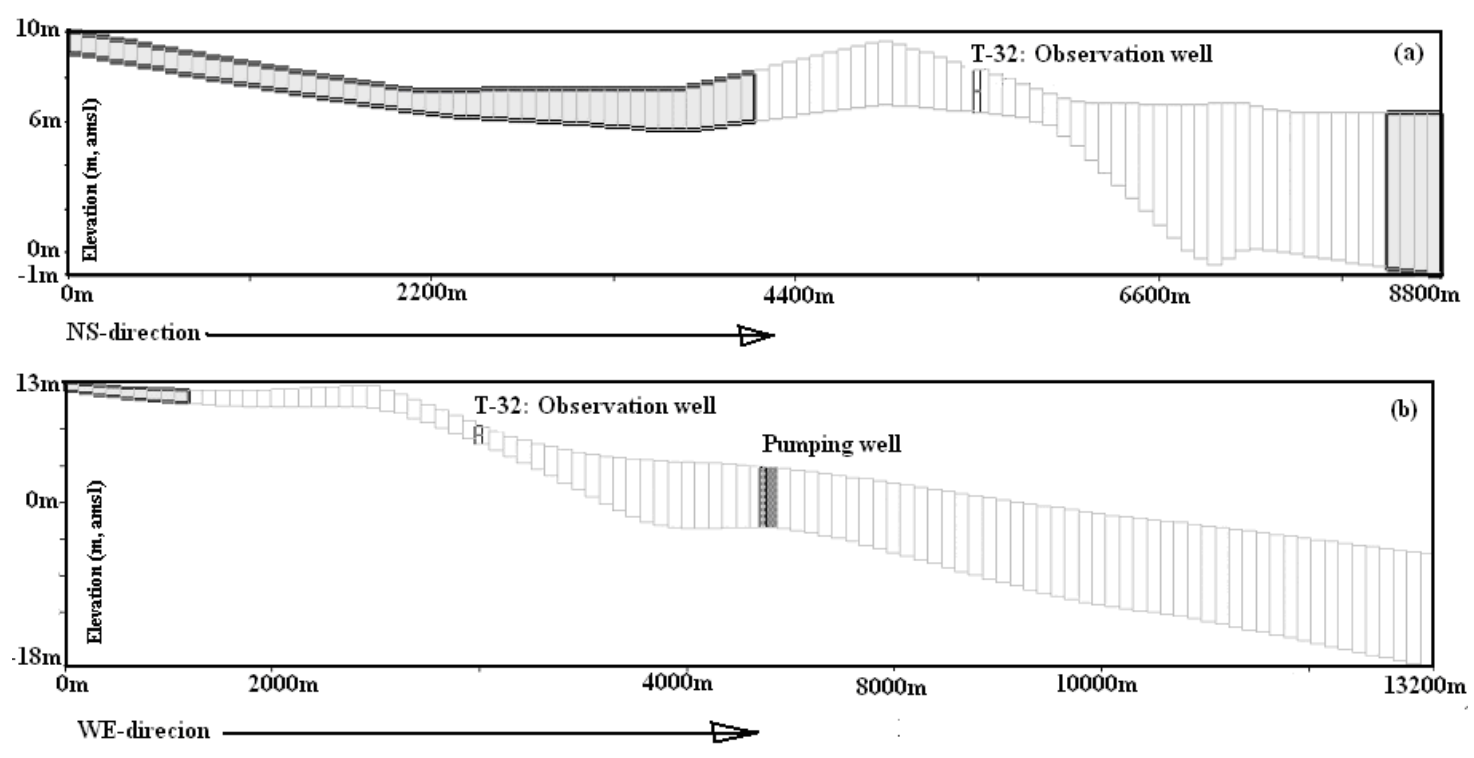

Figure 10. Vertical section view of aquifer in column 31 of model and in row 34 of model.

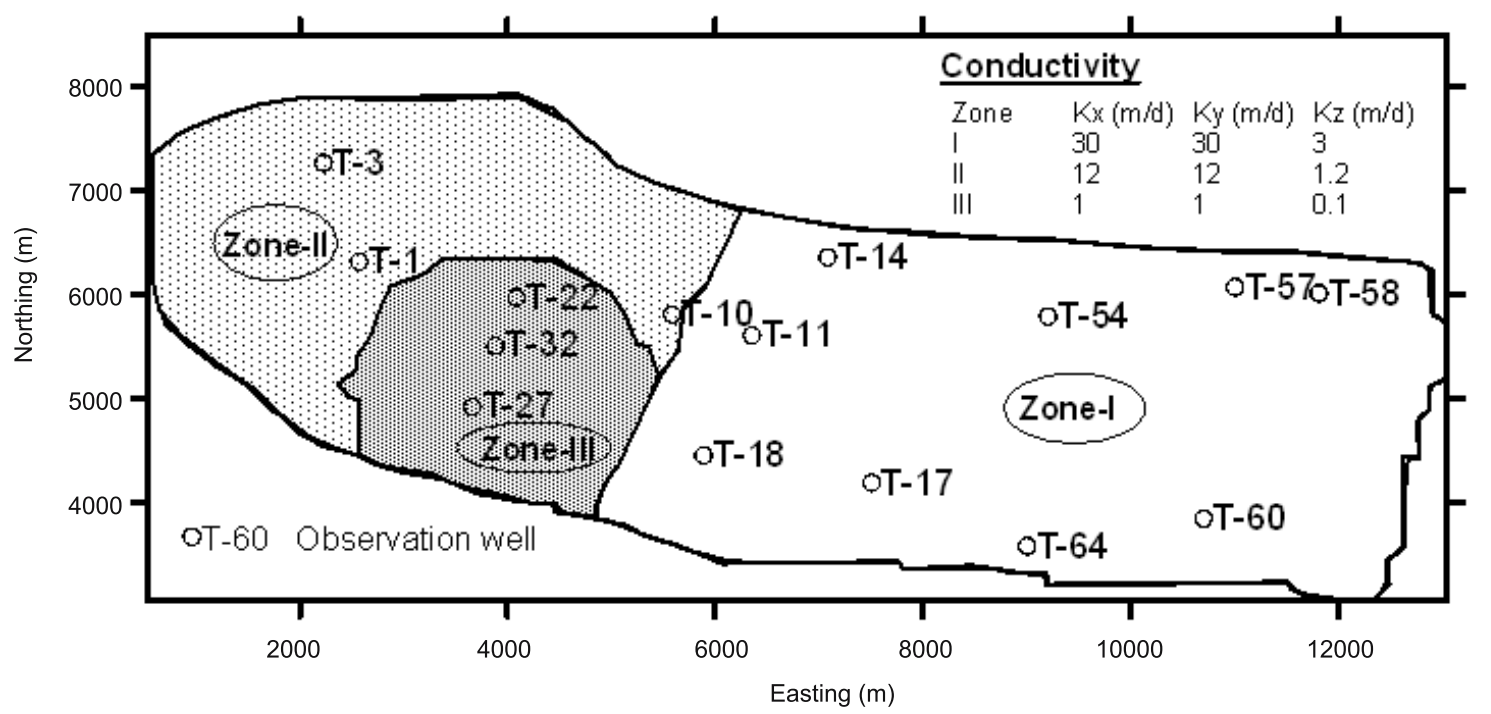

Figure 11. Conductivity distribution and location of pumping wells.

the geology of the area. The conductivity pattern is shown in figure 11 and values vary $1-30 \mathrm{~m} / \mathrm{d}$ from zone to zone. The pumpage from various wells for different purposes have been recorded during field work. An estimation of total pumpage based on the information provided by individual owners/farmers has been calculated. These values have been assigned at respective well locations. Irrigation return is considered as negligible due to rain-fed area. The eastern side of the area is considered as no-flow boundary whereas north and south parts are considered as no-flow boundaries for the parallel groundwater flow in the adjacent formations.

Considering the experiments carried out under tritium studies (Rangarajan et al 2007), geology, surface water body and topographical features, various recharge zones have been identified as shown in figure 12. Initially, the values obtained from tritium experiments have been assigned to these zones; however, these were modified by $\pm 5 \%$ (upward and downward) until the best fit was obtained during the calibration of the model. The recharge value obtained using tritium method and water level change observed in wells were used for estimating the specific yield of the shallow phreatic aquifer system of weathered gneiss, shale limestone and coastal sand formations in the study area. The average specific yield of the phreatic aquifers estimated for weathered gneisses and charnockites, shale limestone and quartzite and coastal alluvium are $5.8 \%, 3.4 \%$ and $9.4 \%$ respectively. 


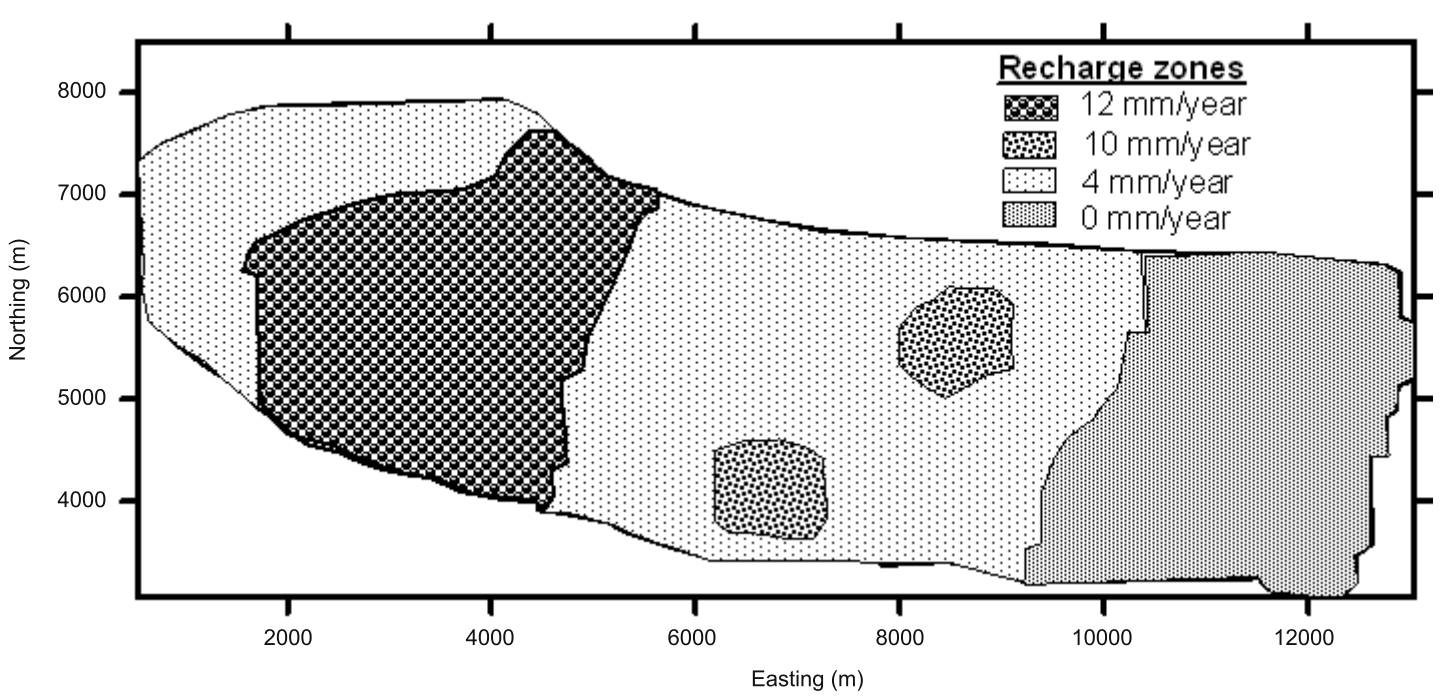

Figure 12. Spatially recharge distribution of the modeled area.

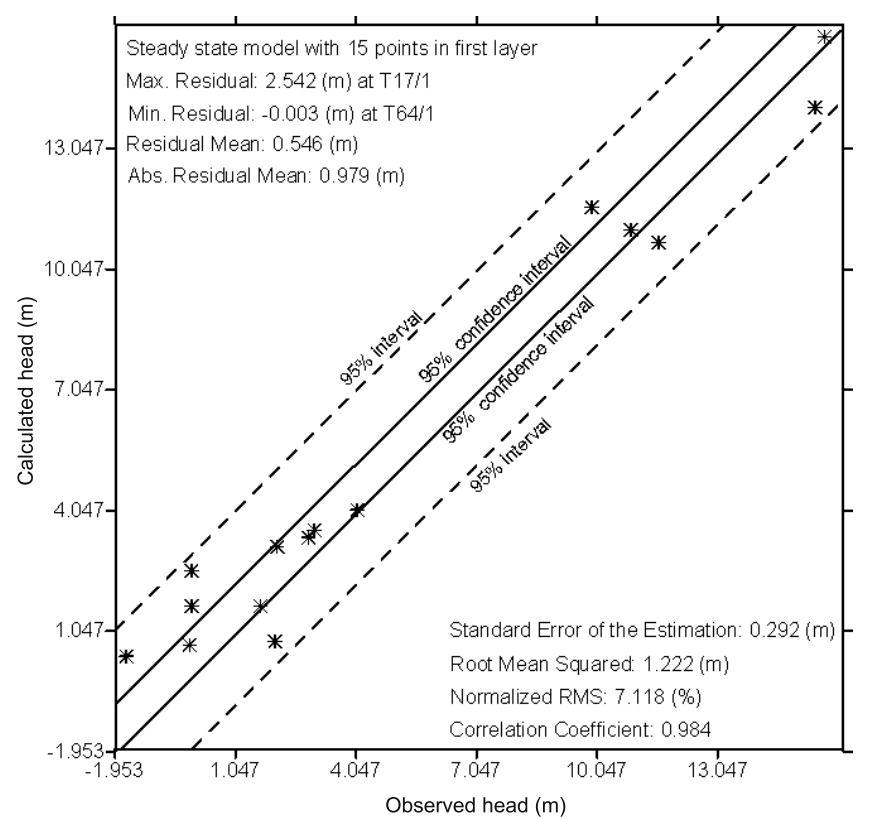

Figure 13. Calculated versus observed heads with $95 \%$ confidence interval.

\subsection{Development of aquifer model}

The various parameters of aquifer have been analyzed to evolve a groundwater flow regime in the study area. The measured inputs such as conductivity, storage coefficient, recharge, groundwater draft were assigned to different zones, considering the hydrogeological conditions. For preparation of aquifer model, Slice Successive Over Relaxation (SSOR) method for solving large systems of linear equations by means of iteration is used which is implemented in the SSOR package of MODFLOW. The model was calibrated by adjusting several parameters (i.e., conductivity, storage coefficient and recharge, etc.) within a narrow range of values (by $\pm 5 \%$ upward and downward) until the best fit was obtained between the observed head at various points and the simulated heads. Comparison of computed versus observed water level has been carried out by computing mean error, mean absolute error and root mean squared error (Anderson and Woessner 1992). All existing observation wells data were included for comparison of computed versus observed heads for steady state simulation. The simulated and observed results compare well as shown in figure 13 . The groundwater velocity vectors obtained from the computed water levels under steady state condition show predominant groundwater flow towards sea. These flow directions are shown in figure 14 . It can be observed that the maximum velocity is about $0.22 \mathrm{~m} / \mathrm{d}$ in the northern part which reduces to near zero as indicated by arrows.

\section{Discussion}

Hydrogeological survey of the study area shows shallow groundwater table conditions in wells of the watershed. Geophysical information in comparison with available litholog data indicates that clayey soil and calcretic clay formations extend up to the depth of $6.2 \mathrm{~m}$ in the area followed by weathered zone of few meters thickness. Borehole tracer studies conducted at a site inside the industrial complex indicate natural groundwater velocity as $0.034 \mathrm{~m} / \mathrm{d}$ considering effective porosity estimated for weathered gneiss and charnockite formations as $5.8 \%$. This value is within the limit of the model result which indicates groundwater velocity varies from $0.22 \mathrm{~m} / \mathrm{d}$ to $0.013 \mathrm{~m} / \mathrm{d}$ in and around the complex area. Borehole tracer experiment and 


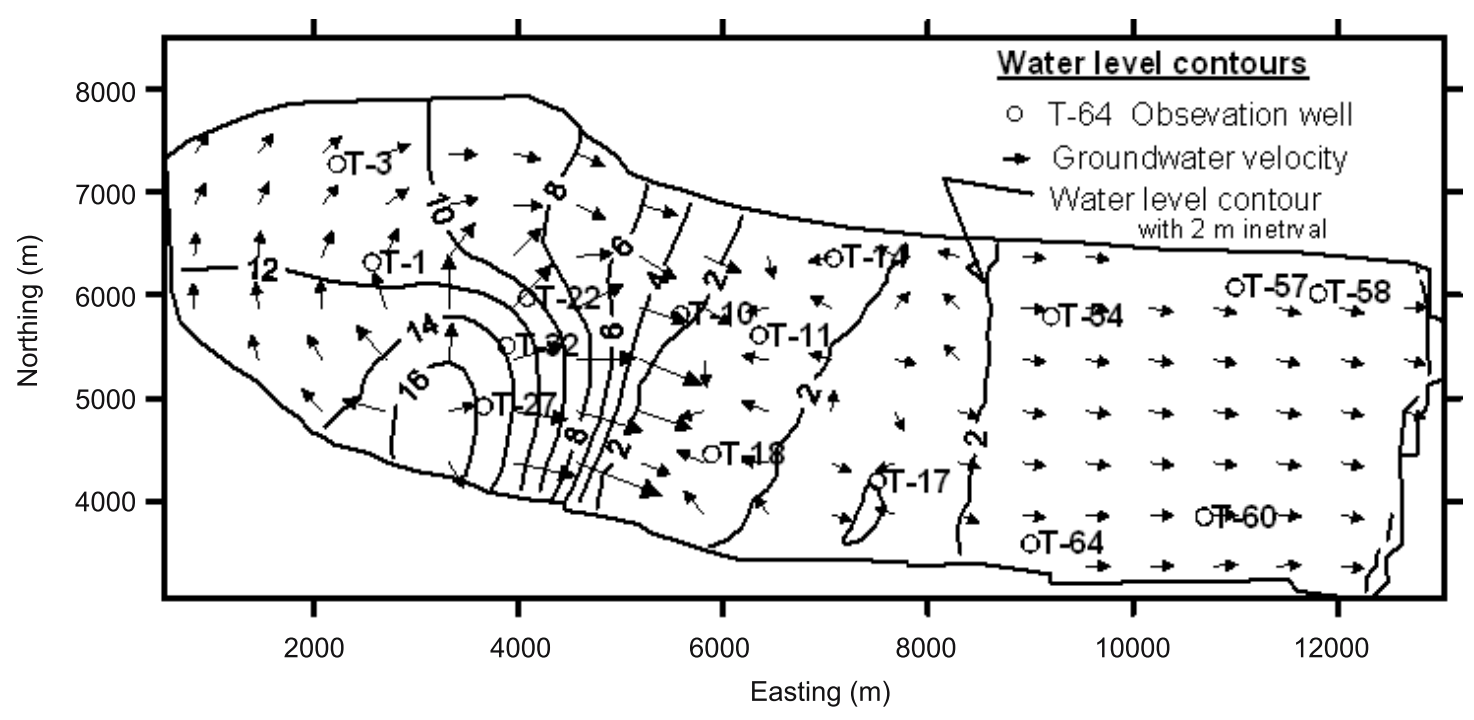

Figure 14. Water level contours map with $2.0 \mathrm{~m}$ intervals and arrows showing the groundwater velocity vectors.

aquifer model study indicate that the velocity of groundwater flow in and around the plant is low. The combination of factors such as the industrial plant area having thick cover of clay soil and calcretic clay formation and low velocity of groundwater flow indicates that there is remote chance for contamination of groundwater sources in the downstream through movement of groundwater with pollutants originated inside the complex. The possible mechanism of contamination of groundwater in the downstream area of the complex may be due to seepage of domestic effluents discharged through surface drains.

\section{Acknowledgements}

Dr V P Dimri, Director of NGRI, Hyderabad has encouraged to carry out various studies in the study area. The entire study was financed by Sterlite Industries India Limited (SIIL), Tuticorin. Officials of SIIL have been always helpful during the field investigation. We have received valuable information from SIIL, Central Ground Water Board, Chennai and Department of Geology, VOC College, Tuticorin. The anonymous reviewers have provided their valuable suggestions to improve the manuscript. We are thankful to all of them.

\section{References}

Anderson M P and Woessner W 1992 Applied ground water modeling - simulation of flow and advective transport (San Diego, C.A., USA: Academic Press).

Athavale R N, Murthy C S and Chand R 1980 Estimation of recharge to the phreatic aquifers of Lower Maner Basin, India by using the tritium injection method; J. Hydrol. 45 185-202.
Balasubramanian A R, Thirugnana Sambandam R, Chellaswamy and Radhakrishnan V 1993 Numerical modeling for prediction and control of saltwater encroachment in the coastal aquifers of Tuticorin, Tamil Nadu; Tech. Report, $21 \mathrm{pp}$.

Bhattacharya P K and Patra H P 1968 Direct current geoelectric sounding - principles and interpretation (Amsterdam: Elsevier) pp 135.

Compagnie General de Geophysique 1963 Master curves for electrical sounding, 2nd edn., European Association of Exploration Geophysicists (EAEG), The Hague, pp 49.

Drost W, Moser H, Neumaier F and Rauert W 1974 Isotope methods in groundwater hydrology; Series Monograph 16, Commission of the European communities, Eurisotop Office Information Booklet, Eurisotop Office: Information \& Documentation Service, pp 176.

Kulkarni U P and Sharma S 2004 Radiotracer technique to quantify change in filtration velocity as a measure of dilution effect by artificial recharge in an arsenic infested aquifer at Ashoknagar Habra-II block, 24 Paraganas district, West Bengal; Published in 15th annual conference of the Indian Nuclear Society (INSAC-2004), Mumbai, India, pp 1-6.

Kumar A, Tomar S, Prasad L B and Prasad B B 2000 Analysis of hydrogeophysical properties of aquifer and reserve estimation for sustainable development of groundwater in Kewta Watershed, Hazaribagh; Proc. Workshop Challenges in Ground Water Development, Central Board of Irrigation and Power, 7-9 June 2000, Tirupati, A.P., pp 325-332.

Munnich K O 1968 Moisture movement measured by isotope tagging; In: Guidebook on Nuclear technique in Hydrology, International Atomic Energy Agency, Vienna, pp $112-117$.

Orellana E and Mooney H M 1966 Master tables and curves for vertical electrical sounding over layered structures; Interciencia, Madrid, Spain, pp 193.

Rangarajan R and Athavale R N 2000 Annual replenishable groundwater potential of India - An estimate based on injected tritium studies; J. Hydrol. 234 38-53.

Rangarajan R, Singh V S, Sankar G B K, Kamale Anand, Hodlur G K, Mondal N C and Somvir Singh 2007 Tracer studies in SIIL watershed, Tuticorin Dist., Tamil Nadu; Tech. Rept. No. NGRI-2007-GW-585, pp 1-29. 
Rijkswaterstaat 1969 Standard graphs for resistivity prospecting, The Netherlands.

Rushton K R and Redshaw S C 1979 Seepage and groundwater flow; John Wiley Publication, pp 339.

Sankul Techno 2002 Geological study and core log test; Report, pp 1-27.

Singh V S 2000 Well storage effect during pumping test in an aquifer of low permeability; Hydrol. Sci. J. 45(4) 589-594.

Singh V S and Mondal N C 2008 Groundwater modeling study of an aquifer around SIIL, Tuticorin, Tamil Nadu; Tech. Rept. No. NGRI-2008-GW-615, pp 1-15.
Singh V S, Mondal N C, Somvir Singh and Negi B C 2006 Hydrogeological and geophysical investigations to delineate aquifer zone around SIIL, Tuticorin, Tamil Nadu; NGRI Tech. Rept. No. NGRI-2006-GW-564, pp 1-25.

Singh V S, Seth D P, Mondal N C and Somvir Singh 2007 Evaluation of aquifer characteristics around SIIL, Tuticorin, Tamil Nadu; Tech. Rept. No. NGRI-2007-GW584, pp 1-19.

Vender Velpen B P A 1988 A computer processing package for D.C. resistivity interpretation for IBM compatibles; ITC J., Vol. 4, The Netherlands. 